Oxford Poverty \& Human Development Initiative (OPHI)

Oxford Department of International Development

Queen Elizabeth House (QEH), University of Oxford

\title{
Multidimensional Poverty Reduction among Countries in Sub-Saharan Africa
}

Sabina Alkire, ${ }^{*}$ Christoph Jindra, ${ }^{* \dagger}$ Gisela Robles-Aguilar,* and Ana Vaz*

July 2017

\begin{abstract}
This paper focuses on changes in multidimensional poverty as measured by the global Multidimensional Poverty Index (global MPI) in Sub-Saharan Africa. Using data for 35 countries, we describe the changes in level, intensity, and composition of multidimensional poverty at the national level. For a subset of countries we discuss results at the subnational level and provide a brief comparison to changes in income poverty. Our findings suggest that 30 countries, home to $92 \%$ of the population in our sample, significantly reduced multidimensional poverty as measured by the global MPI for at least one comparison and significantly reduced the share of poor people. Looking within countries, we find different patterns of poverty reduction, with some countries reducing poverty for the poorest regions while poorer regions in other countries do not seem to benefit from the general reduction in poverty to the same extent. When comparing trends in income and multidimensional poverty reduction we find significant differences, indicating that a holistic approach to poverty reduction should look at both multidimensional and income poverty.
\end{abstract}

A different version of this paper has been previously published as an article by Taylor \& Francis Group in Forum for Social Economics on 10.05.2017, available online: http://dx.doi.org/10.1080/07360932.2017.1310123

Keywords: Sub-Saharan Africa; multidimensional poverty; global MPI; Alkire-Foster method

JEL classification: $\mathrm{O} 15, \mathrm{O} 55$

* Oxford Poverty and Human Development Initiative (OPHI), University of Oxford, UK

†Email: christoph.jindra@qeh.ox.ac.uk.

This study has been prepared within the OPHI theme on multidimensional measurement.

ISSN 2040-8188

ISBN 987-1-907194-91-15 


\section{Acknowledgments}

We would like to thank Usha Kanagaratnam and Christian Oldiges for their help in harmonising the data; our colleagues at OPHI for comments and substantive inputs; Maarit Kivilo for timely support in its preparation; and Nicolai Suppa who was so kind to provide a $\mathrm{IT}_{\mathrm{E} X} \mathrm{X}$-template for the paper. All errors remain our own.

Funder: This work was supported by the Economic and Social Research Council [grant number ES/N01457X/1].

Citation: Alkire, S., Jindra, C., Robles-Aguilar, G., and Vaz, A. (2017). 'Multidimensional poverty reduction among countries in Sub-Saharan Africa.' OPHI Working Paper 112, University of Oxford.

The Oxford Poverty and Human Development Initiative (OPHI) is a research centre within the Oxford Department of International Development, Queen Elizabeth House, at the University of Oxford. Led by Sabina Alkire, OPHI aspires to build and advance a more systematic methodological and economic framework for reducing multidimensional poverty, grounded in people's experiences and values.

The copyright holder of this publication is the Oxford Poverty and Human Development Initiative (OPHI). This publication will be published on the OPHI website and will be archived in the Oxford University Research Archive (ORA) as a Green Open Access publication. The author may submit this paper to other journals.

This publication is covered by copyright; however, it may be reproduced without fee for teaching or non-profit purposes, but not for resale. Formal permission is required for all such uses and will normally be granted immediately. For copying in any other circumstances or for re-use in other publications, translation, or adaptation, prior written permission must be obtained from OPHI and may be subject to a fee.

Oxford Poverty \& Human Development Initiative (OPHI)

Oxford Department of International Development

Queen Elizabeth House (QEH), University of Oxford

3 Mansfield Road, Oxford OX1 3TB, UK

Tel. +44 (0)1865 $271915 \quad$ Fax +44 (0)1865 281801

ophi@qeh.ox.ac.uk http://www.ophi.org.uk

The views expressed in this publication are those of the author(s). Publication does not imply endorsement by OPHI or the University of Oxford, nor by the sponsors, of any of the views expressed. 


\section{Introduction}

The measurement of poverty is not an end in itself. Instead, we measure poverty to help us substantiate claims of levels or changes, to evaluate poverty reduction programmes, or to incentivise certain antipoverty actions. As the Expert Advisory Group on a Data Revolution for Sustainable Development states: 'Without high-quality data, providing the right information on the right things at the right time; designing, monitoring and evaluating effective policies becomes almost impossible' (Independent Expert Advisory Group on a Data Revolution for Sustainable Development, 2014, p. 2). The present research uses a case study of the development of multidimensional poverty in Sub-Saharan Africa to exemplify how data from the global Multidimensional Poverty Index (global MPI), published by the Oxford Poverty and Human Development Initiative, ${ }^{1}$ can be used to assess and describe the evolution of multidimensional poverty.

The paper is structured as follows. We first set forth the global MPI, the data, harmonisation process, and methodology of data analysis. Subsequently we present MPI changes at the national level, followed by subnational poverty reductions by region and decomposition by indicators. We continue with a comparison of trends in income and multidimensional poverty reduction, and their relationship with economic growth, before concluding.

\section{The global MPI and Changes over Time}

Our analysis of the development of multidimensional poverty in Sub-Saharan Africa is based on the global MPI (Alkire and Santos 2014; United Nations Development Programme 2015) The global MPI is an internationally comparable measure of acute multidimensional poverty for developing countries based on the Alkire-Foster method (Alkire and Foster 2011; Alkire et al. 2015). In order to identify the poor, the Alkire-Foster method uses a counting procedure and two different cutoffs. First, people are identified as deprived in each indicator according to a dimension-specific deprivation cutoff. In the second step the number of weighted deprivations (the deprivation score) ${ }^{2}$ is calculated for each individual and a poverty cutoff, which is the number of weighted deprivations a person has to experience to be identified as poor, is applied. After identifying each person as either poor or non-poor, an aggregate measure is computed, in case of the global MPI the adjusted headcount ratio (MO). MO is the product of two partial indices, the headcount ratio $(\mathrm{H})$ and the intensity of poverty (A). The headcount ratio $(\mathrm{H})$ is simply the share of poor people in the population. The intensity $(\mathrm{A})$, which is the average deprivation share among the poor, is calculated by taking the average of the deprivation scores of poor people and shows how many weighted deprivations poor people experience on average.

The global MPI is based on the above procedure using specific deprivation cutoffs and a poverty cutoff of $1 / 3$. It has three dimensions, health, education, and living standards. The health and education dimensions are measured using two indicators each, and the living standards dimension is measured with six indicators. All the dimensions are weighted equally $(1 / 3)$, and the indicators within each dimension receive equal weights as well. The dimensions, their indicators, and respective deprivation cutoffs can be

\footnotetext{
${ }^{1}$ Data can be accessed online at http://www.ophi.org.uk/multidimensional-poverty-index/global-mpi $-2016 /$.

${ }^{2}$ Weights are usually assumed to sum up to one. In this case, the weighted sum of deprivations is the share of weighted deprivations a person experiences.
} 
found in Table 1 (for a detailed discussion see Alkire and Santos (2014)).

\section{Countries, Data, and Analyses}

Our paper applies the methodologies set out in Alkire et al. (2015). We use data from that paper for 19 previously published countries; for nine out of these 19 we append more recent data. We add harmonised data for a further 16 countries. In total, we have results for 35 countries, which were home to around $92 \%$ of the population in Sub-Saharan Africa in 2012. ${ }^{3}$ For ten out of the 35 countries we have data for more than two periods and thus calculate the changes for three time periods, leading to 55 year-to-year comparisons overall. ${ }^{4}$

All data used by Alkire et al. (2015) were Demographic and Health Surveys (DHS) data. For the present study, we include different surveys (see Table 2 in the appendix). Still, most - 40 out of 55 - of the comparisons use DHS data in both time periods. The effective sample size ranges from 10,258 for Sao Tome and Principe in 2000 to 173,218 in Nigeria in 2013, while the average sample size is 41,135.

Published results for the global MPI for the single surveys of each country take the maximum available information in each dataset into account. For the present analysis, data and indicators were strictly harmonised across time periods for each country to permit intertemporal comparisons. Harmonization assures the comparability of the results for each country across years and can involve either dropping an indicator, if the indicator is not available in one of the comparison years, and/or adjusting the definition of the indicator if there were changes in the questionnaires. ${ }^{5}$

In what follows we focus on the discussion of annualised rates of change, as the number of years between the included surveys varies (see Alkire et al. 2015, p. 264ff.). ${ }^{6}$ However, for each poverty estimate, the absolute change was tested for its significance using mean difference tests. ${ }^{7}$ All our surveys use complex survey designs and ignoring the design features can lead to biased population estimates and incorrect statistical inference (for example Kish 1995; Lehtonen and Pahkinen 2004). In order to obtain unbiased variance estimates, the clustering and stratification of each survey was taken into account, viewing the two surveys of the specific country as two super-strata. As the survey design was taken into account, the standard errors in the tables are linearized standard errors. Similarly, the reported t-statistics and their

${ }^{3}$ Population data are from the 2012 revision of the United Nations World Population Prospect (2015).

${ }^{4}$ If the comparison is ambiguous because there are several for one country, we additionally report the time periods that we refer to.

${ }^{5}$ See Alkire et al. (2015) and Alkire et al. (2016) for a detailed description of the harmonisation process. Results for countries with more recent data can additionally differ from Alkire et al. (2015) because countries have then been strictly harmonised across three surveys. Thus, although most of the surveys are published as part of the global MPI, results here can differ from previously published results due to the harmonisation.

${ }^{6}$ Denote $X_{t 1}$ as the achievement matrix in $t_{1}$ and $X_{t 2}$ as the achievement matrix in $t_{2}$. The annualised absolute rate of change is the absolute rate of change divided by the difference between the two years $\bar{\Delta} M P I=\frac{M P I\left(\boldsymbol{X}_{t_{2}}\right)-M P I\left(\boldsymbol{X}_{t_{1}}\right)}{t_{2}-t_{1}}$. The annualised relative rate of change is the compound rate of reduction in $M P I$ between the starting and the end period $\bar{\delta} M P I=\left[\left(\frac{M P I\left(\boldsymbol{X}_{t_{2}}\right)}{M P I\left(\boldsymbol{X}_{t_{1}}\right)}\right)^{\frac{1}{t_{2}-t_{1}}}-1\right] \times 100$. The formulas apply to each of the partial indices as well.

${ }^{7}$ The statistical analysis was done using Stata Version 13.1 (StataCorp 2013). 
respective p-values are survey analysis equivalents of a simple two-sample t-test (compare StataCorp 2013, p. 110).

The global MPI is calculated for observations that do not have missing values for any of the indicators. If the decrease in sample size was high, a bias analysis was also undertaken in the form of t-tests in order to assess whether we find significant and systematic differences in the deprivations of the remaining indicators between those who are missing the indicators with the highest frequency of missing values and those who are not missing these indicators. In line with Alkire and Santos (2014), we undertook bias analyses for the entire country if we lost $13 \%$ or more of the sample, and for subnational analyses if the sample size was reduced by $13 \%$ or more in a specific region. This type of test is similar to tests of whether or not data are missing completely at random (MCAR). Although a lack of support for the alternative hypothesis, implying that the data are not missing at random, cannot be interpreted as evidence of MCAR, as the probability of 'missingness' can still be related to the values of the actual variable (Enders 2010; Allison 2002), it allows us to assess if we can expect some sort of bias in our estimates. Among the surveys for which we have large shares of missing values, we find indications of a slight underestimation of poverty for Mauritania in 2007 and 2011, Namibia in 2007, as well as Gabon in 2000, and of a slight overestimation for Sao Tome and Principe in 2000. None of the subnational regions showed any indication of bias.

The annualised growth rates of GDP per capita (in constant 2005 US Dollars) were calculated using GDP per capita information from the World Development Indicators of the World Bank (2015). ${ }^{8}$ Data for the poverty headcount ratio at $\$ 1.90$ a day (2011 PPP) were taken from the same source. In order to obtain estimates of the income poverty levels for countries for which the World Bank does not provide data for the same year, we interpolated or extrapolated the numbers from the information we have following the procedure of Alkire, Roche and Vaz (2015 and forthcoming). ${ }^{9}$

\section{Changes in Multidimensional Poverty}

Table 3 in the appendix reports the main statistics for changes in MPI at the national level. The countries in our sample have very different initial levels of poverty, with MPI ranging from .076 for South Africa in 2008 to .696 for Niger in year 2006. We find significant absolute reductions in MPI for most countries. ${ }^{10}$ Around $85.5 \%$ of the comparisons show significant progress in reducing multidimensional poverty, and $92 \%$ of the population in our sample lives in a country that experienced poverty reductions for at least one comparison. Exceptions are Zimbabwe, Togo, Sierra Leone, and Senegal. ${ }^{11}$ Nigeria

\footnotetext{
${ }^{8}$ We use the dataset provided by the Quality of Government Institute (Teorell et al. 2016) to merge GDP and income poverty data with the multidimensional poverty data. The world development indicators in this dataset were downloaded on the 02.11.2015 from http://go.worldbank.org/2EAGGLRZ40.

${ }^{9}$ In cases where the headcount ratio $\mathrm{H}$ (or poverty gap) is missing, the value in year $t$ is calculated by finding the two closest points $\left(H_{0}, t_{0}\right)$ and $\left(H_{1}, t_{1}\right)$ where $t_{0}<t$ and $t_{1}>t$ for which we have observed $H_{t 0}$ and $H_{t 1}$ and $H_{t}$ is then interpolated using $H_{t}=\frac{H_{1}-H_{0}}{t_{1}-t_{0}}\left(t-t_{0}\right)+H_{0}$. Extrapolation uses the two closest points on the same side of $t$ and the same formula.

${ }^{10}$ If not mentioned otherwise, we use $\alpha=0.05$.

${ }^{11}$ The timing of the surveys seems to matter for whether or not we find a significant reduction in MPI. Countries with significant reductions have, on average, surveys that are 6.8 years apart, while countries with non-significant reductions have surveys that are, on average, 4.5 years apart. The difference is statistically significant $(t(53)=2.42$, p-value $=0.019)$.
} 
Figure 1: Change in $H$ and $A$ for all comparisons

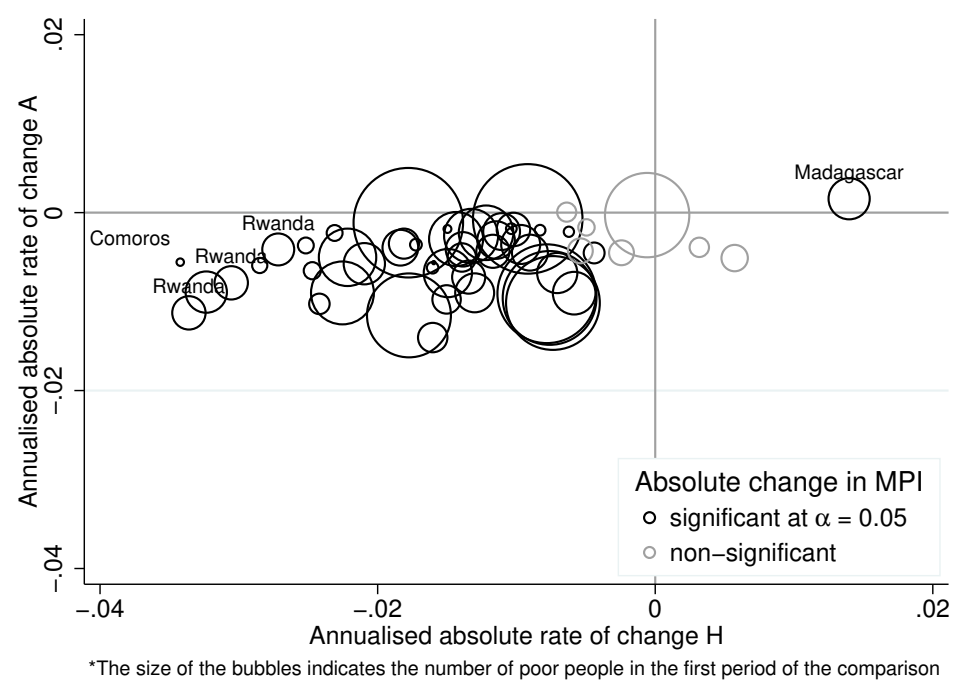

reduced multidimensional poverty between 2003 and 2008 but did not make significant progress between 2008 and 2013. For Madagascar, our data support the conclusion that multidimensional poverty significantly increased between 2004 and 2008/9.

Based on the annualised absolute changes, we find that the four countries with the highest reductions are Rwanda for the time periods 2005 - 2010 and 2005 - 2014/15, Liberia and Ghana for the period 2003 2008, and the Comoros, which all have annualised rates of reductions above -0.02. Rwanda shows the fastest national poverty reduction at a rate of -0.026 and clearly outperforms other countries.

MPI can be reduced by reducing $\mathrm{H}$, reducing A, or reducing both. In our sample, as in the case of MPI, 85.5\% of comparisons of $\mathrm{H}$ and $76.4 \%$ of comparisons of $\mathrm{A}$ show significant absolute reductions. Figure 1 shows the annualised absolute changes in $\mathrm{H}$ and $\mathrm{A}$. Countries in the lower left corner reduced both $\mathrm{A}$ and $\mathrm{H}$ strongly. Countries in the upper left corner would have reduced $\mathrm{H}$ rather more than $\mathrm{A}$, while those in the lower right corner have reduced A more than $\mathrm{H}$. Finally, countries in the upper right corner showed increases in both $\mathrm{H}$ and $\mathrm{A}$. The graph additionally distinguishes between countries with significant absolute changes in MPI and those without. The light circles close to the origin denote countries for which our data do not support the conclusion of a significant absolute change in MPI. The dark circle in the upper right corner is Madagascar, which had a significant increase in MPI. This increase is mainly due to an increase in $\mathrm{H}$, while the increase in $\mathrm{A}$ is statistically non-significant (results for $\mathrm{H}$ and $\mathrm{A}$ can be found in Tables 4 and 5 in the appendix). The graph suggests that countries generally have higher annualised reductions in $\mathrm{H}$ than $\mathrm{A}$, as expected, and that there is more variation in the annualised changes in $\mathrm{H}$. All countries with significant reductions in MPI also significantly reduced $\mathrm{H}$ and those without reductions in MPI also did not reduce $\mathrm{H}^{12}$

We find the highest reduction in $\mathrm{H}$ for Comoros, which reduced the share of people living in multidimensional poverty by over 40 percentage points between 2000 and 2011, from $73.9 \%$ to $32.8 \%$. Rwanda reduced $\mathrm{H}$ by nearly 30 percentage points in the time between 2005 and $2014 / 15$, from $82.9 \%$ to

${ }^{12}$ Again based on $\alpha=0.05$. 
$53.9 \%$. For both countries, the large improvement in $\mathrm{H}$ outpaced population growth, thus leading to a reduction in the absolute number of poor.

The data of 32 countries can be disaggregated by subnational regions. ${ }^{13}$ We thus have representative subnational data for 272 regions in 32 countries, and 386 subnational comparisons overall. ${ }^{14}$ We find great subnational disparities within countries. For Kenya in 2003, we have a range in MPI of 0.633 , where the capital Nairobi is by far the least poor region (MPI $=0.048$ ) while the North Eastern region is the poorest with an MPI of 0.681 . In contrast, the three subnational regions of Malawi show a much smaller range of 0.096, with levels of MPI between 0.298 and 0.393 .

When looking at the subnational level, $67.6 \%$ of the regions, which are home to $62 \%$ of the population in the 32 countries, show significant reductions in MPI for at least one comparison. We find that ten countries significantly reduced poverty in all subnational regions for at least one comparison. These countries are Benin, Ethiopia for 2000 - 2011, Gabon, Gambia, Ghana for 2003 - 2008 and 2003 - 2014, Liberia, Malawi, Mozambique, Niger, and Rwanda for 2005 - 2010 and 2005 - 2014/15. Five countries on the other hand, Madagascar, Senegal for 2010/11 - 2012/13, Sierra Leone, Togo, and Zimbabwe, have not made progress in any subnational region.

Figure 2 shows the annualised absolute subnational reductions in MPI versus MPI in the initial period for Mauritania, Benin, Mali, and Guinea. These four countries show two different types of poverty reduction. For Mauritania and Benin we find that, in general, subnational regions with higher initial poverty levels reduced poverty the most. In contrast, for Mali and Guinea we find that, even though there were many similarly poor regions in the initial period, the pace of poverty reduction between the regions varies and some of the regions that were equally poor originally did not make significant progress. Thus we find that some of the countries experienced types of poverty reductions that generally benefited the poorer regions more, helping those to catch up, while for other countries, not all the poor regions benefited equally from the general progress in terms of poverty reduction. When looking only at the comparisons between the earliest and most recent data available for each country, we find that $71.9 \%$ of the countries, home to $69.9 \%$ of the population of this study, reduced the gap between the poorest and the least poor regions. Eight countries have the largest reductions for the poorest subnational region. The countries are Cote d'Ivoire, Kenya (2003 - 2008/9 and 2003 - 2014), Liberia, Mozambique, Malawi, Namibia (2000 - 2006/7 and 2000 - 2013), Niger, and Nigeria (2008 - 2013).

The analysis of subnational regions allows us to identify regions that are outstanding regarding their reduction of multidimensional poverty. By outstanding we mean regions that perform better in terms of the annualised absolute changes in MPI than the leading country at the aggregate level, Rwanda. We find that 20 regions, home to $6 \%$ of the population in our countries, perform better. ${ }^{15}$ These regions and a range of related statistics can be found in Table 6 in descending order according to their annualised absolute reductions in MPI. We find that they vary regarding MPI in the initial period between 0.269 to 0.681. But most of them have a high MPI and incidence of poverty in the initial period (60\% of these

\footnotetext{
${ }^{13}$ Assuming we have $m$ groups and the population share of group $l$ is given by $v^{l}=\frac{n^{l}}{n}$, we can express MPI at the national level, given a specific achievement matrix $X$, as the population share weighted subgroup poverty levels: $M P I=\sum_{l=1}^{m} v^{l} M P I\left(X^{l}\right)$.

${ }^{14}$ The survey design does not allow decomposition by region for Zambia, South Africa, and the Comoros. ${ }^{15}$ The results are descriptive as the data do not allow significance tests for the annualised changes.
} 
Figure 2: Subnational reductions in MPI versus MPI in initial period
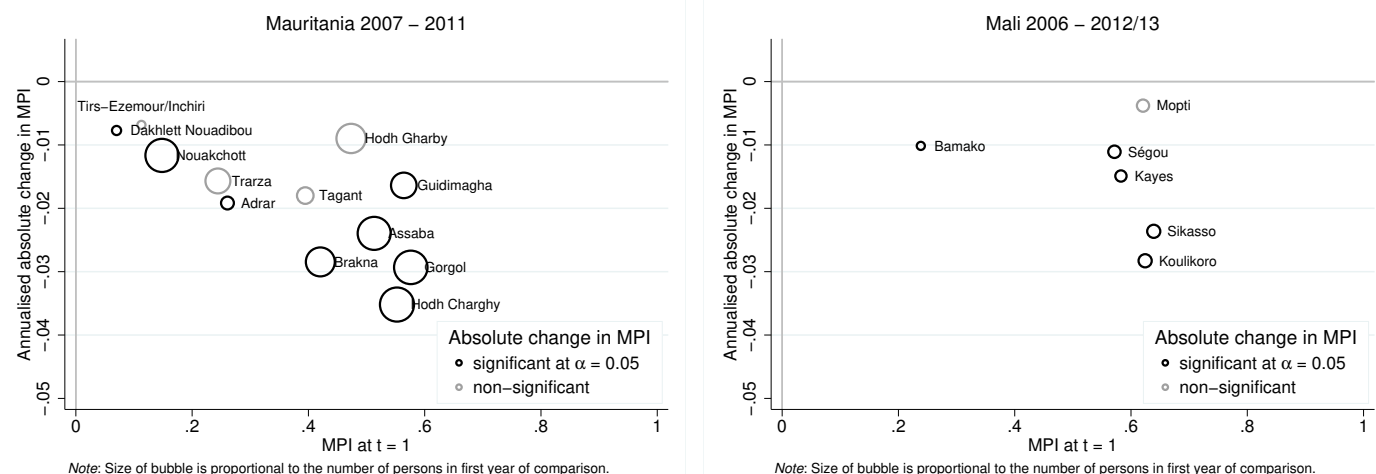

Note: Size of bubble is proportional to the number of persons in first year of comparison
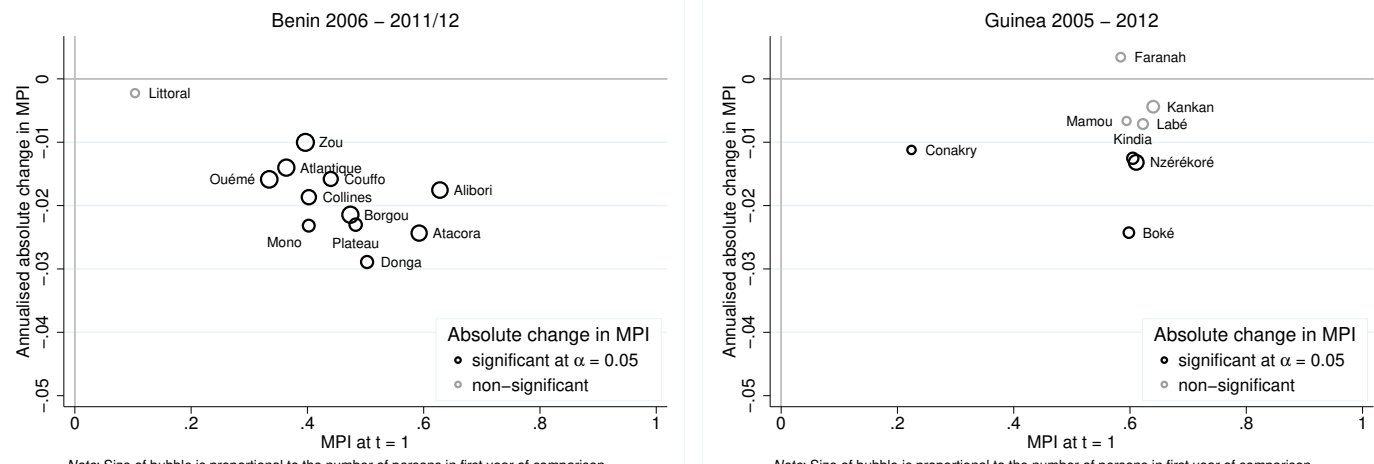

regions have an initial $\mathrm{H}$ of $80 \%$ or above).

When looking at the annualised absolute rate of change in MPI, four out of the five best performing regions are in the Republic of the Congo for the comparison between 2009 and 2011/12. In that time period, MPI was reduced from 0.389 to 0.273 in the region of Likouala, leading to an annualised absolute reduction of -0.046 . Seven regions have annualised absolute reductions in MPI larger than -0.03 .

Nord-Kivu in the DR Congo shows the highest absolute reduction in $\mathrm{H}$ from $94.4 \%$ to $67 \%$ between 2007 and 2013/14. However, while Nord-Kivu had the highest absolute reduction, we find even higher annualised absolute rates of reduction in the incidence of poverty for other regions - because their comparisons were for shorter time periods. By far the biggest annualised absolute reduction can be found in Likouala in the Republic of the Congo with a value of -0.079 , which translated into a reduction of the initial headcount ratio from $73.9 \%$ to $54.1 \%$ for the years compared here.

The global MPI can be further decomposed by indicators. Out of the 32 countries, nine reduced the share of people who are poor and deprived in a specific indicator for all of the ten MPI indicators. These countries are Zambia, Kenya, Ethiopia, Burkina Faso, Mozambique, Comoros, Ghana, Rwanda, and Gabon. For Madagascar, the data do not show a significant reduction in the censored headcount ratios for any of the indicators. Fourteen regions in six countries (Benin, Ethiopia, Ghana, Kenya, Mali, and Rwanda) reduced the censored headcount ratios of all indicators. Table 7 in the appendix shows the ranking of the significant reductions among the indicators for each countries. The indicator that is most often reduced is toilet, followed by assets. 
Figure 3: Annualised relative changes in multidimensional and income poverty

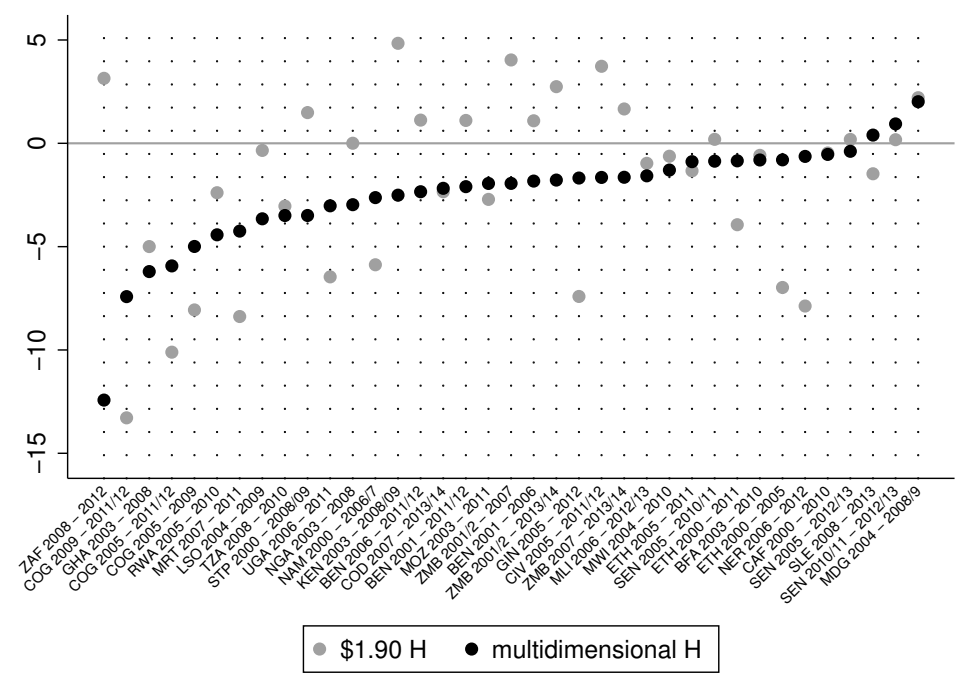

\section{Multidimensional Poverty, Income Poverty, and Economic Growth}

Due to the novelty of the multidimensional approach, a natural question to ask is if we arrive at the same conclusion when using the income approach. This section presents a brief comparison between reductions in multidimensional poverty and income poverty as measured by $\$ 1.90$ a day.

We restrict the discussion to countries for which we have information on both multidimensional and income poverty, after extra- or interpolation of the income data, leaving us with an effective sample size of 27 countries and 37 comparisons. ${ }^{16}$

Figure 3 gives a graphical comparison of the annualised relative changes in the headcount ratios for income and multidimensional poverty. We find that there are countries for which the trends are fairly similar, like Mali, Malawi, and Burkina Faso. However, for many countries the rates differ markedly. Guinea and Niger, for example, experienced large reductions in income poverty, but small reductions in terms of multidimensional poverty. On the other hand, for quite a few countries, looking only at income poverty reductions would mask achievements in multidimensional poverty. This is particularly striking in the case of South Africa, which experienced an increase in income poverty but is the leader in relative terms in multidimensional poverty reduction.

Table 8 in the appendix reports the compound annual growth rate of GDP per capita in constant 2005 US\$. We find that the countries are very diverse in their economic development, with South Africa being by far the richest as measured by GDP per capita in the initial time period, followed by Namibia. The countries with the lowest GDP per capita in the first period are Ethiopia and Malawi. We also find very different growth rates. Nigeria experienced economic growth of over $8 \%$ for the time period between 2003 and 2008, while Ethiopia also had a growth rate of $8 \%$ for the period between 2005 and

\footnotetext{
${ }^{16}$ We only extra- or interpolate the income headcount ratio if we have information on income poverty available that is less than four years from the years of the surveys used for estimating multidimensional poverty.
} 
Figure 4: Annualised relative changes versus growth in GDP per capita

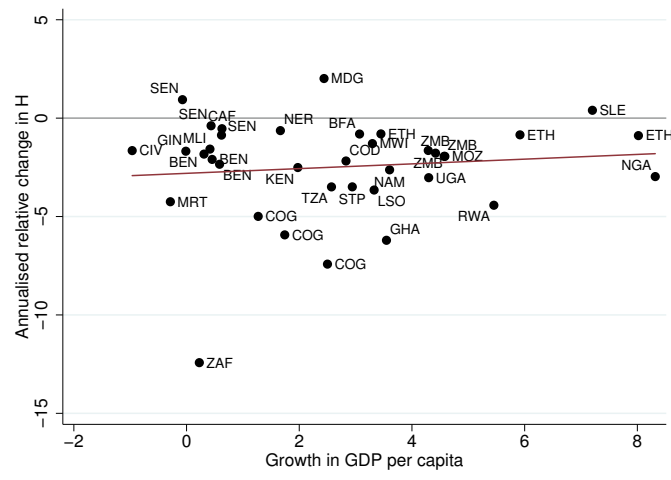

(a) Multidimensional poverty

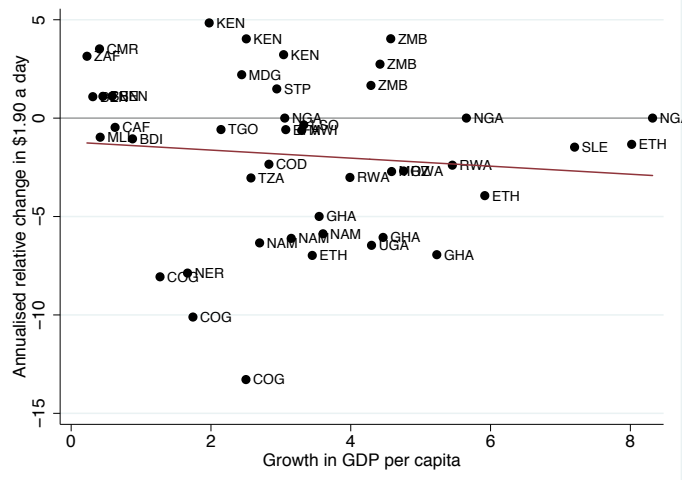

(b) Income poverty

2011. South Africa, on the other hand, had the lowest growth rate, followed by Benin (2001 and 2006) and Mali. Four countries had negative growth.

Figure 4 shows the relationship between the annualised relative reductions in the multidimensional headcount ratio and the income headcount ratio versus growth in GDP per capita. Despite the differences in the conclusions when comparing reductions in multidimensional and income poverty within countries, the graphs seem to indicate that there is no clear, strong relationship between growth and either of the headcount ratios. Although the estimated regression lines have different signs, the estimated relationships are far from statistically significant. ${ }^{17}$ Thus, our data do not support the conclusion that higher growth in GDP is associated with smaller reductions in multidimensional poverty. For multidimensional poverty, the conclusion does not change when looking at MPI or A. The data also do not support the conclusion that higher economic growth is associated with higher reductions in income poverty. However, despite the impression of a similar conclusion from the scatter plots, the one for income poverty seems to indicate that there are some potentially influential cases, like Guinea and Mauritania, which could drive the results, while the graph for multidimensional poverty does not indicate influential cases.

\section{Conclusions}

Our results support the conclusion that most of the countries in Sub-Saharan Africa in our sample made progress in terms of multidimensional poverty, with a few exceptions. When looking at the reduction in multidimensional poverty at the subnational level, we find great disparities within and between countries. While many countries reduced the gap between the poorest and the least poor region, only a few countries had the highest reduction in the poorest region. Looking at the subnational level, we find huge within-country differences across regions. These subnational results can be used as the starting point for in-depth analyses of the causes of successful poverty reduction, which might otherwise be hidden behind national averages.

When comparing the results of the changes in multidimensional poverty to the changes in income

${ }^{17}$ In case of the relationship between the multidimensional $H$ and growth in GDP per capita we get $\hat{\beta}=$ 0.12 , s.e. $=0.18$, $\mathrm{t}$-value $=.65$. For income poverty we get $\hat{\beta}=-0.16$, s.e. $=0.31, \mathrm{t}$-value $=-.05$. 
poverty, we find that the two approaches give slightly different answers to the question of where poverty was reduced. While some countries reduced both, we find many countries for which multidimensional poverty decreases and income poverty increases. If monetary and multidimensional poverty measures moved together, and if they both identified the same people as poor, there would be no need for two separate measures. Due to the kind of data we use, our results cannot give us any further clue as to whether or not we identify the same people or not. Nonetheless, we find that the measures do indeed not necessarily go in the same direction. Policy interventions should therefore be oriented towards reducing all forms of poverty and having separate poverty measures provides the information policy makers need. Despite the different picture in terms of absolute reductions, similar to other studies (Donaldson 2008; Ferreira et al. 2010), we do not find a clear relationship between economic growth and poverty reduction. Our findings suggest that economic growth alone might not be sufficient to reduce multidimensional poverty. 


\section{References}

Alkire, S. and J. Foster (2011). Counting and Multidimensional Poverty Measurement. Journal of Public Economics 95(7-8), 476-487.

Alkire, S., J. Foster, S. Seth, M. E. Santos, J. M. Roche, and P. Ballon (2015). Multidimensional Poverty Measurement and Analysis. Oxford, New York: Oxford University Press.

Alkire, S., C. Jindra, G. Robles, and A. Vaz (2016). Multidimensional Poverty Index Summer 2016: Brief Methodological Note and Results. OPHI Briefing 42.

Alkire, S., J. M. Roche, and A. Vaz (2015). Changes Over Time in Multidimensional Poverty: Methodology and Results for 34 Countries. OPHI Working Paper 76. University of Oxford.

Alkire, S., J. M. Roche, and A. Vaz (forthcoming). Changes Over Time in Multidimensional Poverty: Methodology and Results for 34 Countries. World Development.

Alkire, S. and M. E. Santos (2014). Measuring Acute Poverty in the Developing World: Robustness and Scope of the Multidimensional Poverty Index. World Development 59, 251-274.

Allison, P. D. (2002). Missing Data, Volume 07-136 of Sage University Paper Series on Quantitative Applications in the Social Sciences. Thousand Oaks, CA: SAGE.

Donaldson, J. A. (2008). Growth is Good for Whom, When, How? Economic Growth and Poverty Reduction in Exceptional Cases. World Development 36(11), 2127-2143.

Enders, C. K. (2010). Applied Missing Data Analysis. New York and London: The Guildford Press.

Ferreira, F. H., P. G. Leite, and M. Ravallion (2010). Poverty Reduction without Economic Growth? Journal of Development Economics 93(1), 20-36.

Kish, L. (1995). Survey Sampling (New edition ed.). New York: Wiley-Blackwell.

Lehtonen, R. and E. Pahkinen (2004). Practical Methods for Design and Analysis of Complex Surveys. The Atrium; Southern Gate; Chichester: Wiley.

StataCorp (2013). Stata Statistical Software: Release 13. College Station, TX: StataCorp LP. 
StataCorp (2013). Stata Survey Data Reference Manual - Release 13. College Station, Texas: Stata Press.

Teorell, J., S. Dahlberg, S. Holmberg, B. Rothstein, A. Khomenko, and R. Svenson (2016). The Quality of Government Standard Dataset, Version Jan16. University of Gothenburg: Quality of Government Institute.

United Nations, Department of Economic and Social Affairs, Population Division (2015). World Population Prospects: The 2015 Revision, DVD Edition.

United Nations Development Programme (Ed.) (2015). Work for Human Development. Human Development Report 2015. Houndmills: Palgrave Macmillan. 


\section{Appendix A}

Table 1: Dimensions, indicators and cutoffs global MPI (Alkire et al. 2015, p. 169)

\begin{tabular}{|c|c|c|}
\hline Dimensions & Indicator (weight) & Deprivation Cutoff \\
\hline \multirow[t]{2}{*}{ Education } & Schooling $(1 / 6)$ & $\begin{array}{l}\text { No household member has completed five years of } \\
\text { schooling }\end{array}$ \\
\hline & Attendance $(1 / 6)$ & $\begin{array}{l}\text { Any school-aged child in the household is not attending } \\
\text { school up to class } 8\end{array}$ \\
\hline \multirow[t]{2}{*}{ Health } & Nutrition $(1 / 6)$ & $\begin{array}{l}\text { And adult or child in the household with nutritional } \\
\text { information is undernourished }\end{array}$ \\
\hline & Mortality (1/6) & $\begin{array}{l}\text { Any child has passed away in the household in the last } 5 \\
\text { years }\end{array}$ \\
\hline \multirow[t]{6}{*}{ Standard of living } & Electricity $(1 / 18)$ & The household has no electricity \\
\hline & Sanitation $(1 / 18)$ & $\begin{array}{l}\text { The household's sanitation facility is not improved or is } \\
\text { shared with other households }\end{array}$ \\
\hline & Water $(1 / 18)$ & $\begin{array}{l}\text { The household does not have access to safe drinking water, } \\
\text { or safe water is more than a 30-minute walk (round trip) }\end{array}$ \\
\hline & $(1 / 18)$ & The household has a dirt, sand, or dung floor \\
\hline & Cooking fuel $(1 / 18)$ & The household cooks with dung, wood, or charcoal \\
\hline & Assets (1/18) & $\begin{array}{l}\text { The household owns at most one asset (radio, telephone, } \\
\text { TV, bike, motorbike, or refrigerator) and does not own a } \\
\text { car }\end{array}$ \\
\hline
\end{tabular}


Table 2: Countries, year comparison and data

\begin{tabular}{|c|c|c|c|c|c|}
\hline \multirow{2}{*}{ Country } & \multirow{2}{*}{ Year Comparison } & \multirow{2}{*}{ Data } & \multicolumn{2}{|c|}{ Sample size } & \multirow{2}{*}{ ISO-code } \\
\hline & & & $t_{1}$ & $t_{2}$ & \\
\hline Burundi & $2005-2010$ & MICS - DHS & 40591 & 41283 & BDI \\
\hline Benin & $2006-2011 / 12$ & DHS - DHS & 84139 & 84871 & $\mathrm{BEN}$ \\
\hline Benin & $2001-2006$ & DHS - DHS & 29299 & 84139 & BEN \\
\hline Benin & $2001-2011 / 12$ & DHS - DHS & 29299 & 84871 & $\mathrm{BEN}$ \\
\hline Burkina Faso & $2003-2010$ & DHS - DHS/MICS & 58916 & 39095 & BFA \\
\hline C. African Republic & $2000-2010$ & MICS - MICS & 80964 & 50566 & CAF \\
\hline Cote d'Ivoire & $2005-2011 / 12$ & DHS - DHS/MICS & 22885 & 49306 & CIV \\
\hline Cameroon & $2004-2011$ & DHS - DHS & 23117 & 34965 & CMR \\
\hline DR Congo & $2007-2013 / 14$ & DHS - DHS & 20891 & 43322 & COD \\
\hline The Republic of the Congo & $2009-2011 / 12$ & DHS - DHS & 28550 & 48920 & COG \\
\hline The Republic of the Congo & $2005-2009$ & DHS - DHS & 28887 & 28550 & COG \\
\hline The Republic of the Congo & $2005-2011 / 12$ & DHS - DHS & 28887 & 48920 & COG \\
\hline Comoros & $2000-2012$ & MICS - DHS/MICS & 20192 & 21375 & $\mathrm{COM}$ \\
\hline Ethiopia & $2005-2011$ & DHS - DHS & 30461 & 71967 & ETH \\
\hline Ethiopia & $2000-2011$ & DHS - DHS & 65600 & 71967 & ETH \\
\hline Ethiopia & $2000-2005$ & DHS - DHS & 65600 & 30461 & ETH \\
\hline Gabon & $2000-2012$ & DHS - DHS & 22557 & 26663 & GAB \\
\hline Ghana & $2008-2014$ & DHS - DHS & 21237 & 21250 & GHA \\
\hline Ghana & $2003-2008$ & DHS - DHS & 25500 & 21237 & GHA \\
\hline Ghana & $2003-2014$ & DHS - DHS & 25500 & 21250 & GHA \\
\hline Guinea & $2005-2012$ & DHS - DHS/MICS & 18365 & 21843 & GIN \\
\hline Gambia & $2006-2013$ & MICS - DHS & 41931 & 48267 & GMB \\
\hline Kenya & $2003-2008 / 09$ & DHS - DHS & 35417 & 37132 & KEN \\
\hline Kenya & $2008 / 9-2014$ & DHS - DHS & 37132 & 58440 & KEN \\
\hline Kenya & $2003-2014$ & DHS - DHS & 35417 & 58440 & KEN \\
\hline Liberia & $2007-2013$ & DHS - DHS & 33190 & 21958 & LBR \\
\hline Lesotho & $2004-2009$ & DHS - DHS & 14870 & 16477 & LSO \\
\hline Madagascar & $2004-2008 / 9$ & DHS - DHS & 36080 & 35024 & MDG \\
\hline Mali $^{\circ}$ & $2006-2012 / 13$ & DHS - DHS & 19693 & 27197 & MLI \\
\hline Mozambique & $2003-2011$ & DHS - DHS & 59262 & 61368 & MOZ \\
\hline Mauritania & $2007-2011$ & MICS - MICS & 50271 & 51353 & MRT \\
\hline Malawi & $2004-2010$ & DHS - DHS & 57047 & 38502 & MWI \\
\hline Namibia & $2000-2006 / 7$ & DHS - DHS & 25302 & 33875 & NAM \\
\hline Namibia & $2006 / 7-2013$ & DHS - DHS & 33875 & 16075 & NAM \\
\hline Namibia & $2000-2013$ & DHS - DHS & 25302 & 16075 & NAM \\
\hline Niger & $2006-2012$ & DHS - DHS & 22223 & 27918 & NER \\
\hline Nigeria & $2003-2008$ & DHS - DHS & 33889 & 150394 & NGA \\
\hline Nigeria & $2003-2013$ & DHS - DHS & 33889 & 173218 & NGA \\
\hline Nigeria & $2008-2013$ & DHS - DHS & 150394 & 173218 & NGA \\
\hline Rwanda & $2010-2014 / 15$ & DHS - DHS & 27269 & 26694 & RWA \\
\hline Rwanda & $2005-2014 / 15$ & DHS - DHS & 22818 & 26694 & RWA \\
\hline Rwanda & $2005-2010$ & DHS - DHS & 22818 & 27269 & RWA \\
\hline Senegal & $2010 / 11-2012 / 13$ & DHS/MICS - Continuous DHS & 25452 & 37666 & SEN \\
\hline Senegal & $2005-2010 / 11$ & DHS - DHS/MICS & 18815 & 25452 & SEN \\
\hline Senegal & $2005-2012 / 13$ & DHS - Continous DHS & 18815 & 37666 & SEN \\
\hline Sierra Leone & $2008-2013$ & DHS - DHS & 19061 & 35559 & SLE \\
\hline Sao Tome and Principe & $2000-2008 / 09$ & MICS - DHS & 10258 & 12588 & STP \\
\hline Togo & $2010-2013 / 14$ & MICS - DHS & 29381 & 21311 & TGO \\
\hline Tanzania & $2008-2010$ & DHS - DHS & 42867 & 48046 & TZA \\
\hline Uganda & $2006-2011$ & DHS - DHS & 13783 & 13004 & UGA \\
\hline South Africa & $2008-2012$ & NIDS - NIDS & 26439 & 29705 & ZAF \\
\hline Zambia & $2001 / 2-2013 / 14$ & DHS - DHS & 36449 & 79597 & $\mathrm{ZMB}$ \\
\hline Zambia & $2007-2013 / 14$ & DHS - DHS & 34136 & 79597 & $\mathrm{ZMB}$ \\
\hline Zambia & $2001 / 2-2007$ & DHS - DHS & 36449 & 34136 & $\mathrm{ZMB}$ \\
\hline Zimbabwe & $2010 / 11-2014$ & DHS - MICS & 34682 & 61976 & ZWE \\
\hline
\end{tabular}


Table 3: National results for MPI

\begin{tabular}{|c|c|c|c|c|c|c|}
\hline \multirow{2}{*}{ Country (year comparison) } & \multicolumn{2}{|c|}{$M P I$} & \multirow{2}{*}{$\begin{array}{c}\text { Absolute } \\
\text { change }(\triangle M P I)\end{array}$} & \multirow{2}{*}{$\begin{array}{l}\text { t-value } \\
(\triangle M P I)\end{array}$} & \multicolumn{2}{|c|}{ Annualised change } \\
\hline & $t_{1}$ (s.e.) & $t_{2}$ (s.e.) & & & Absolute & Relative \\
\hline Burundi $(2005$ - 2010) & $0.503(0.006)$ & $0.434(0.006)$ & $-0.068^{* * *}$ & 8.000 & -0.014 & -0.029 \\
\hline Benin $(2006-2011 / 12)$ & $0.414(0.006)$ & $0.314(0.004)$ & $-0.099^{* * *}$ & 13.477 & -0.018 & -0.049 \\
\hline Benin $(2001-2006)$ & $0.474(0.008)$ & $0.414(0.006)$ & $-0.060^{* * *}$ & 5.875 & -0.012 & -0.027 \\
\hline Benin $(2001-2011 / 12)$ & $0.474(0.008)$ & $0.314(0.004)$ & $-0.159^{* * *}$ & 17.278 & -0.015 & -0.038 \\
\hline Burkina Faso (2003 - 2010) & $0.620(0.007)$ & $0.545(0.006)$ & $-0.074^{* * *}$ & 7.898 & -0.011 & -0.018 \\
\hline C. African Republic $(2000-2010)$ & $0.503(0.005)$ & $0.440(0.005)$ & $-0.062^{* * *}$ & 8.890 & -0.006 & -0.013 \\
\hline Cote d'Ivoire (2005 - 2011/12) & $0.353(0.010)$ & $0.304(0.008)$ & $-0.049^{* * * *}$ & 3.874 & -0.008 & -0.023 \\
\hline Cameroon $(2004-2011)$ & $0.298(0.009)$ & $0.248(0.007)$ & $-0.050^{* * *}$ & 4.390 & -0.007 & -0.026 \\
\hline DR Congo $(2007$ - 2013/14) & $0.527(0.011)$ & $0.401(0.008)$ & $-0.127^{* * *}$ & 9.176 & -0.019 & -0.041 \\
\hline The Republic of the Congo $(2009-2011 / 12)$ & $0.208(0.005)$ & $0.167(0.005)$ & $-0.041^{* * *}$ & 5.566 & -0.017 & -0.085 \\
\hline The Republic of the Congo $(2005-2009)$ & $0.260(0.010)$ & $0.208(0.005)$ & $-0.052^{* * *}$ & 4.694 & -0.013 & -0.054 \\
\hline The Republic of the Congo $(2005-2011 / 12)$ & $0.260(0.010)$ & $0.167(0.005)$ & $-0.093^{* * *}$ & 8.610 & -0.014 & -0.066 \\
\hline Comoros $(2000$ - 2012) & $0.408(0.012)$ & $0.159(0.009)$ & $-0.249^{* * *}$ & 16.751 & -0.021 & -0.075 \\
\hline Ethiopia (2005 - 2011) & $0.604(0.006)$ & $0.526(0.007)$ & $-0.078^{* * *}$ & 8.657 & -0.013 & -0.023 \\
\hline Ethiopia $(2000$ - 2011) & $0.677(0.004)$ & $0.526(0.007)$ & $-0.150^{* * *}$ & 18.600 & -0.014 & -0.023 \\
\hline Ethiopia $(2000-2005)$ & $0.677(0.004)$ & $0.604(0.006)$ & $-0.072^{* * *}$ & 10.529 & -0.014 & -0.022 \\
\hline Gabon $(2000-2012)$ & $0.161(0.006)$ & $0.075(0.004)$ & $-0.086^{* * *}$ & 10.740 & -0.007 & -0.061 \\
\hline Ghana $(2008-2014)$ & $0.207(0.007)$ & $0.167(0.007)$ & $-0.040^{* * *}$ & 4.074 & -0.007 & -0.035 \\
\hline Ghana $(2003-2008)$ & $0.311(0.007)$ & $0.207(0.007)$ & $-0.104^{* * *}$ & 10.763 & -0.021 & -0.079 \\
\hline Ghana $(2003$ - 2014) & $0.311(0.007)$ & $0.167(0.007)$ & $-0.144^{* * *}$ & 14.650 & -0.013 & -0.055 \\
\hline Guinea (2005 - 2012) & $0.557(0.007)$ & $0.472(0.011)$ & $-0.085^{* * *}$ & 6.554 & -0.012 & -0.023 \\
\hline Gambia (2006 - 2013) & $0.336(0.008)$ & $0.253(0.008)$ & $-0.083^{* * *}$ & 6.982 & -0.012 & -0.040 \\
\hline Kenya $(2003-2008 / 09)$ & $0.299(0.008)$ & $0.251(0.010)$ & $-0.048^{* * *}$ & 3.875 & -0.009 & -0.031 \\
\hline Kenya $(2008 / 9-2014)$ & $0.251(0.010)$ & $0.213(0.004)$ & $-0.038^{* * *}$ & 3.692 & -0.007 & -0.029 \\
\hline Kenya $(2003-2014)$ & $0.299(0.008)$ & $0.213(0.004)$ & $-0.085^{* * *}$ & 9.953 & -0.008 & -0.030 \\
\hline Liberia (2007 - 2013) & $0.485(0.008)$ & $0.358(0.008)$ & $-0.127^{* * *}$ & 10.976 & -0.021 & -0.049 \\
\hline Lesotho (2004 - 2009) & $0.238(0.005)$ & $0.190(0.007)$ & $-0.048^{* * *}$ & 5.086 & -0.010 & -0.044 \\
\hline Madagascar (2004 - 2008/9) & $0.374(0.015)$ & $0.414(0.007)$ & $0.040^{* * *}$ & 2.642 & 0.009 & 0.023 \\
\hline Mali (2006 - 2012/13) & $0.559(0.009)$ & $0.459(0.010)$ & $-0.100^{* * *}$ & 7.435 & -0.015 & -0.030 \\
\hline Mozambique (2003 - 2011) & $0.505(0.007)$ & $0.393(0.007)$ & $-0.112^{* * *}$ & 11.855 & -0.014 & -0.031 \\
\hline Mauritania $(2007$ - 2011) & $0.355(0.006)$ & $0.285(0.006)$ & $-0.070^{* * *}$ & 8.162 & -0.018 & -0.054 \\
\hline Malawi (2004 - 2010) & $0.381(0.006)$ & $0.334(0.005)$ & $-0.047^{* * *}$ & 6.063 & -0.008 & -0.022 \\
\hline Namibia $(2000$ - 2006/7) & $0.199(0.008)$ & $0.163(0.005)$ & $-0.036^{* * *}$ & 3.867 & -0.006 & -0.030 \\
\hline Namibia (2006/7 - 2013) & $0.163(0.005)$ & $0.140(0.006)$ & $-0.023^{* * *}$ & 3.035 & -0.004 & -0.023 \\
\hline Namibia $(2000-2013)$ & $0.199(0.008)$ & $0.140(0.006)$ & $-0.059^{* * *}$ & 5.997 & -0.005 & -0.027 \\
\hline Niger $(2006-2012)$ & $0.696(0.007)$ & $0.621(0.007)$ & $-0.075^{* * *}$ & 7.803 & -0.012 & -0.019 \\
\hline Nigeria $(2003-2008)$ & $0.368(0.011)$ & $0.313(0.006)$ & $-0.055^{* * *}$ & 4.537 & -0.011 & -0.032 \\
\hline Nigeria $(2003$ - 2013) & $0.368(0.011)$ & $0.311(0.007)$ & $-0.057^{* * *}$ & 4.538 & -0.006 & -0.017 \\
\hline Nigeria $(2008$ - 2013) & $0.313(0.006)$ & $0.311(0.007)$ & -0.002 & 0.271 & -0.000 & -0.002 \\
\hline Rwanda $(2010-2014 / 15)$ & $0.330(0.005)$ & $0.259(0.005)$ & $-0.071^{* * *}$ & 9.889 & -0.016 & -0.052 \\
\hline Rwanda $(2005-2014 / 15)$ & $0.461(0.005)$ & $0.259(0.005)$ & $-0.202^{* * *}$ & 29.174 & -0.021 & -0.059 \\
\hline Rwanda (2005 - 2010) & $0.461(0.005)$ & $0.330(0.005)$ & $-0.131^{* * *}$ & 17.377 & -0.026 & -0.064 \\
\hline Senegal $(2010 / 11-2012 / 13)$ & $0.351(0.011)$ & $0.352(0.012)$ & 0.000 & 0.019 & 0.000 & 0.000 \\
\hline Senegal $(2005$ - 2010/11) & $0.383(0.019)$ & $0.351(0.011)$ & -0.032 & 1.463 & -0.006 & -0.016 \\
\hline Senegal $(2005-2012 / 13)$ & $0.383(0.019)$ & $0.352(0.012)$ & -0.032 & 1.407 & -0.004 & -0.012 \\
\hline Sierra Leone $(2008$ - 2013) & $0.470(0.008)$ & $0.464(0.008)$ & -0.006 & 0.524 & -0.001 & -0.003 \\
\hline Sao Tome and Principe $(2000-2008 / 09)$ & $0.272(0.012)$ & $0.182(0.008)$ & $-0.089^{* * *}$ & 6.093 & -0.010 & -0.046 \\
\hline Togo $(2010-2013 / 14)$ & $0.250(0.007)$ & $0.239(0.010)$ & -0.011 & 0.969 & -0.003 & -0.013 \\
\hline Tanzania $(2008-2010)$ & $0.371(0.008)$ & $0.335(0.007)$ & $-0.037^{* * *}$ & 3.482 & -0.018 & -0.050 \\
\hline Uganda (2006 - 2011) & $0.420(0.007)$ & $0.343(0.009)$ & $-0.077^{* * *}$ & 5.826 & -0.015 & -0.039 \\
\hline South Africa (2008 - 2012) & $0.076(0.005)$ & $0.043(0.004)$ & $-0.033^{* * *}$ & 5.184 & -0.008 & -0.133 \\
\hline Zambia $(2001 / 2$ - 2013/14) & $0.400(0.008)$ & $0.292(0.005)$ & $-0.108^{* * *}$ & 12.185 & -0.009 & -0.026 \\
\hline Zambia $(2007$ - 2013/14) & $0.333(0.007)$ & $0.292(0.005)$ & $-0.041^{* * *}$ & 5.008 & -0.006 & -0.020 \\
\hline Zambia $(2001 / 2-2007)$ & $0.400(0.008)$ & $0.333(0.007)$ & $-0.067^{* * *}$ & 6.523 & -0.012 & -0.033 \\
\hline Zimbabwe (2010/11 - 2014) & $0.136(0.005)$ & $0.127(0.003)$ & -0.009 & 1.561 & -0.003 & -0.020 \\
\hline
\end{tabular}


Table 4: National results for $\mathrm{H}$

\begin{tabular}{|c|c|c|c|c|c|c|}
\hline \multirow{2}{*}{ Country (year comparison) } & \multicolumn{2}{|c|}{$H$} & \multirow{2}{*}{$\begin{array}{c}\text { Absolute } \\
\text { change }(\Delta H)\end{array}$} & \multirow{2}{*}{$\begin{array}{l}\text { t-value } \\
(\Delta H)\end{array}$} & \multicolumn{2}{|c|}{ Annualised change } \\
\hline & $t_{1}$ (s.e.) & $t_{2}$ (s.e.) & & & Absolute & Relative \\
\hline Burundi $(2005-2010)$ & $0.819(0.008)$ & $0.728(0.008)$ & $-0.091^{* * *}$ & 8.027 & -0.018 & -0.023 \\
\hline Benin $(2006-2011 / 12)$ & $0.721(0.008)$ & $0.633(0.007)$ & $-0.088^{* * *}$ & 8.264 & -0.016 & -0.023 \\
\hline Benin $(2001-2006)$ & $0.791(0.009)$ & $0.721(0.008)$ & $-0.070^{* * *}$ & 5.844 & -0.014 & -0.018 \\
\hline Benin $(2001-2011 / 12)$ & $0.791(0.009)$ & $0.633(0.007)$ & $-0.158^{* * *}$ & 13.696 & -0.015 & -0.021 \\
\hline Burkina Faso (2003 - 2010) & $0.896(0.007)$ & $0.847(0.007)$ & $-0.049^{* * *}$ & 5.268 & -0.007 & -0.008 \\
\hline C. African Republic $(2000-2010)$ & $0.840(0.005)$ & $0.796(0.007)$ & $-0.044^{* * *}$ & 4.954 & -0.004 & -0.005 \\
\hline Cote d'Ivoire $(2005$ - 2011/12) & $0.615(0.014)$ & $0.552(0.011)$ & $-0.063^{* * *}$ & 3.566 & -0.010 & -0.017 \\
\hline Cameroon $(2004-2011)$ & $0.538(0.013)$ & $0.460(0.011)$ & $-0.077^{* * *}$ & 4.768 & -0.011 & -0.022 \\
\hline DR Congo (2007 - 2013/14) & $0.865(0.012)$ & $0.750(0.012)$ & $-0.115^{* * *}$ & 6.726 & -0.018 & -0.022 \\
\hline The Republic of the Congo $(2009-2011 / 12)$ & $0.406(0.011)$ & $0.335(0.010)$ & $-0.071^{* * *}$ & 4.919 & -0.028 & -0.074 \\
\hline The Republic of the Congo $(2005-2009)$ & $0.499(0.017)$ & $0.406(0.011)$ & $-0.092^{* * *}$ & 4.581 & -0.023 & -0.050 \\
\hline The Republic of the Congo $(2005-2011 / 12)$ & $0.499(0.017)$ & $0.335(0.010)$ & $-0.164^{* * *}$ & 8.264 & -0.025 & -0.059 \\
\hline Comoros $(2000-2012)$ & $0.739(0.015)$ & $0.328(0.016)$ & $-0.411^{* * *}$ & 19.150 & -0.034 & -0.065 \\
\hline Ethiopia $(2005$ - 2011) & $0.899(0.006)$ & $0.852(0.008)$ & $-0.047^{* * *}$ & 4.666 & -0.008 & -0.009 \\
\hline Ethiopia $(2000$ - 2011) & $0.936(0.003)$ & $0.852(0.008)$ & $-0.084^{* * *}$ & 9.221 & -0.008 & -0.008 \\
\hline Ethiopia (2000 - 2005) & $0.936(0.003)$ & $0.899(0.006)$ & $-0.037^{* * *}$ & 5.681 & -0.007 & -0.008 \\
\hline Gabon $(2000-2012)$ & $0.354(0.012)$ & $0.174(0.010)$ & $-0.180^{* * *}$ & 10.825 & -0.015 & -0.057 \\
\hline Ghana (2008 - 2014) & $0.428(0.012)$ & $0.359(0.013)$ & $-0.069^{* * *}$ & 3.894 & -0.011 & -0.029 \\
\hline Ghana (2003 - 2008) & $0.590(0.011)$ & $0.428(0.012)$ & $-0.162^{* * *}$ & 9.831 & -0.032 & -0.062 \\
\hline Ghana (2003 - 2014) & $0.590(0.011)$ & $0.359(0.013)$ & $-0.231^{* * *}$ & 13.498 & -0.021 & -0.044 \\
\hline Guinea (2005 - 2012) & $0.867(0.007)$ & $0.770(0.013)$ & $-0.097^{* * *}$ & 6.419 & -0.014 & -0.017 \\
\hline Gambia (2006 - 2013) & $0.625(0.011)$ & $0.512(0.014)$ & $-0.112^{* * *}$ & 6.098 & -0.016 & -0.028 \\
\hline Kenya (2003 - 2008/09) & $0.605(0.012)$ & $0.526(0.016)$ & $-0.079^{* * *}$ & 3.906 & -0.014 & -0.025 \\
\hline Kenya $(2008 / 9-2014)$ & $0.526(0.016)$ & $0.459(0.007)$ & $-0.067^{* * *}$ & 3.759 & -0.012 & -0.024 \\
\hline Kenya $(2003-2014)$ & $0.605(0.012)$ & $0.459(0.007)$ & $-0.146^{* * *}$ & 10.382 & -0.013 & -0.025 \\
\hline Liberia (2007 - 2013) & $0.839(0.010)$ & $0.694(0.013)$ & $-0.145^{* * *}$ & 8.790 & -0.024 & -0.031 \\
\hline Lesotho (2004 - 2009) & $0.508(0.010)$ & $0.422(0.014)$ & $-0.086^{* * *}$ & 4.759 & -0.017 & -0.037 \\
\hline Madagascar (2004 - 2008/9) & $0.670(0.021)$ & $0.733(0.011)$ & $0.063^{* * *}$ & 2.875 & 0.014 & 0.020 \\
\hline Mali $(2006-2012 / 13)$ & $0.863(0.011)$ & $0.779(0.013)$ & $-0.085^{* * *}$ & 4.921 & -0.013 & -0.016 \\
\hline Mozambique (2003 - 2011) & $0.823(0.007)$ & $0.703(0.010)$ & $-0.120 * * *$ & 9.902 & -0.015 & -0.019 \\
\hline Mauritania $(2007$ - 2011) & $0.620(0.009)$ & $0.521(0.010)$ & $-0.099^{* * *}$ & 7.413 & -0.025 & -0.042 \\
\hline Malawi (2004 - 2010) & $0.721(0.010)$ & $0.667(0.008)$ & $-0.054^{* * *}$ & 4.330 & -0.009 & -0.013 \\
\hline Namibia $(2000$ - 2006/7) & $0.424(0.016)$ & $0.357(0.010)$ & $-0.067^{* * *}$ & 3.623 & -0.010 & -0.026 \\
\hline Namibia (2006/7 - 2013) & $0.357(0.010)$ & $0.316(0.012)$ & $-0.040^{* * *}$ & 2.621 & -0.006 & -0.018 \\
\hline Namibia $(2000$ - 2013) & $0.424(0.016)$ & $0.316(0.012)$ & $-0.108^{* * *}$ & 5.392 & -0.008 & -0.022 \\
\hline Niger (2006 - 2012) & $0.935(0.005)$ & $0.900(0.006)$ & $-0.035^{* * *}$ & 4.623 & -0.006 & -0.006 \\
\hline Nigeria $(2003$ - 2008) & $0.636(0.016)$ & $0.547(0.009)$ & $-0.089^{* * *}$ & 4.956 & -0.018 & -0.030 \\
\hline Nigeria (2003 - 2013) & $0.636(0.016)$ & $0.544(0.009)$ & $-0.092^{* * *}$ & 5.013 & -0.009 & -0.015 \\
\hline Nigeria (2008 - 2013) & $0.547(0.009)$ & $0.544(0.009)$ & -0.003 & 0.230 & -0.001 & -0.001 \\
\hline Rwanda (2010 - 2014/15) & $0.661(0.009)$ & $0.539(0.009)$ & $-0.122^{* * *}$ & 9.566 & -0.027 & -0.044 \\
\hline Rwanda (2005 - 2014/15) & $0.829(0.008)$ & $0.539(0.009)$ & $-0.290^{* * *}$ & 25.261 & -0.031 & -0.044 \\
\hline Rwanda $(2005$ - 2010) & $0.829(0.008)$ & $0.661(0.009)$ & $-0.168^{* * *}$ & 13.946 & -0.034 & -0.044 \\
\hline Senegal $(2010 / 11-2012 / 13)$ & $0.607(0.016)$ & $0.619(0.019)$ & 0.011 & 0.462 & 0.006 & 0.009 \\
\hline Senegal $(2005-2010 / 11)$ & $0.637(0.026)$ & $0.607(0.016)$ & -0.030 & 0.954 & -0.005 & -0.009 \\
\hline Senegal (2005 - 2012/13) & $0.637(0.026)$ & $0.619(0.019)$ & -0.018 & 0.564 & -0.002 & -0.004 \\
\hline Sierra Leone $(2008-2013)$ & $0.791(0.010)$ & $0.807(0.011)$ & 0.016 & 1.055 & 0.003 & 0.004 \\
\hline Sao Tome and Principe $(2000-2008 / 09)$ & $0.520(0.020)$ & $0.385(0.016)$ & $-0.136^{* * *}$ & 5.327 & -0.016 & -0.035 \\
\hline Togo $(2010-2013 / 14)$ & $0.497(0.011)$ & $0.480(0.015)$ & -0.017 & 0.922 & -0.005 & -0.010 \\
\hline Tanzania $(2008-2010)$ & $0.656(0.012)$ & $0.611(0.011)$ & $-0.045^{* * *}$ & 2.877 & -0.023 & -0.035 \\
\hline Uganda (2006 - 2011) & $0.779(0.011)$ & $0.668(0.015)$ & $-0.111^{* * *}$ & 5.248 & -0.022 & -0.030 \\
\hline South Africa (2008 - 2012) & $0.178(0.011)$ & $0.105(0.008)$ & $-0.073^{* * *}$ & 5.204 & -0.018 & -0.124 \\
\hline Zambia $(2001 / 2$ - 2013/14) & $0.724(0.012)$ & $0.584(0.008)$ & $-0.140^{* * * *}$ & 9.569 & -0.012 & -0.018 \\
\hline Zambia $(2007-2013 / 14)$ & $0.650(0.012)$ & $0.584(0.008)$ & $-0.066^{* * *}$ & 4.535 & -0.010 & -0.016 \\
\hline Zambia $(2001 / 2$ - 2007) & $0.724(0.012)$ & $0.650(0.012)$ & $-0.074^{* * *}$ & 4.278 & -0.013 & -0.019 \\
\hline Zimbabwe (2010/11 - 2014) & $0.319(0.011)$ & $0.297(0.008)$ & $-0.022^{*}$ & 1.676 & -0.006 & -0.020 \\
\hline
\end{tabular}


Table 5: National results for $\mathrm{A}$

\begin{tabular}{|c|c|c|c|c|c|c|}
\hline \multirow{2}{*}{ Country (year comparison) } & \multicolumn{2}{|c|}{$A$} & \multirow{2}{*}{$\begin{array}{c}\text { Absolute } \\
\text { change }(\Delta A)\end{array}$} & \multirow{2}{*}{$\begin{array}{l}\text { t-value } \\
(\Delta A)\end{array}$} & \multicolumn{2}{|c|}{ Annualised change } \\
\hline & $t_{1}$ (s.e.) & $t_{2}$ (s.e.) & & & Absolute & Relative \\
\hline Burundi $(2005-2010)$ & $0.614(0.004)$ & $0.597(0.003)$ & $-0.017^{* * *}$ & 3.483 & -0.003 & -0.006 \\
\hline Benin $(2006-2011 / 12)$ & $0.574(0.004)$ & $0.497(0.002)$ & $-0.077^{* * *}$ & 18.218 & -0.014 & -0.026 \\
\hline $\operatorname{Benin}(2001-2006)$ & $0.599(0.006)$ & $0.574(0.004)$ & $-0.025^{* * *}$ & 3.645 & -0.005 & -0.009 \\
\hline Benin $(2001-2011 / 12)$ & $0.599(0.006)$ & $0.497(0.002)$ & $-0.102^{* * *}$ & 16.381 & -0.010 & -0.018 \\
\hline Burkina Faso $(2003-2010)$ & $0.692(0.005)$ & $0.644(0.004)$ & $-0.048^{* * *}$ & 7.384 & -0.007 & -0.010 \\
\hline C. African Republic $(2000-2010)$ & $0.599(0.003)$ & $0.553(0.003)$ & $-0.045^{* * *}$ & 9.875 & -0.005 & -0.008 \\
\hline Cote d'Ivoire (2005 - 2011/12) & $0.574(0.007)$ & $0.551(0.004)$ & $-0.023^{* * *}$ & 2.884 & -0.004 & -0.006 \\
\hline Cameroon $(2004-2011)$ & $0.553(0.007)$ & $0.538(0.007)$ & -0.015 & 1.483 & -0.002 & -0.004 \\
\hline DR Congo $(2007-2013 / 14)$ & $0.609(0.007)$ & $0.534(0.004)$ & $-0.075^{* * *}$ & 8.936 & -0.012 & -0.020 \\
\hline The Republic of the Congo $(2009-2011 / 12)$ & $0.512(0.004)$ & $0.497(0.003)$ & $-0.015^{* * *}$ & 2.894 & -0.006 & -0.012 \\
\hline The Republic of the Congo $(2005-2009)$ & $0.521(0.005)$ & $0.512(0.004)$ & -0.009 & 1.388 & -0.002 & -0.004 \\
\hline The Republic of the Congo $(2005-2011 / 12)$ & $0.521(0.005)$ & $0.497(0.003)$ & $-0.024^{* * *}$ & 3.762 & -0.004 & -0.007 \\
\hline Comoros $(2000-2012)$ & $0.552(0.008)$ & $0.486(0.009)$ & $-0.067^{* * *}$ & 5.690 & -0.006 & -0.011 \\
\hline Ethiopia $(2005-2011)$ & $0.672(0.004)$ & $0.618(0.005)$ & $-0.055^{* * *}$ & 8.861 & -0.009 & -0.014 \\
\hline Ethiopia $(2000$ - 2011) & $0.723(0.003)$ & $0.618(0.005)$ & $-0.105^{* * *}$ & 18.609 & -0.010 & -0.014 \\
\hline Ethiopia $(2000-2005)$ & $0.723(0.003)$ & $0.672(0.004)$ & $-0.051^{* * *}$ & 10.315 & -0.010 & -0.014 \\
\hline Gabon $(2000-2012)$ & $0.455(0.004)$ & $0.433(0.004)$ & $-0.022^{* * *}$ & 3.461 & -0.002 & -0.004 \\
\hline Ghana $(2008-2014)$ & $0.482(0.005)$ & $0.464(0.006)$ & $-0.019^{* *}$ & 2.261 & -0.003 & -0.006 \\
\hline Ghana (2003 - 2008) & $0.527(0.004)$ & $0.482(0.005)$ & $-0.045^{* * *}$ & 6.694 & -0.009 & -0.018 \\
\hline Ghana (2003 - 2014) & $0.527(0.004)$ & $0.464(0.006)$ & $-0.063^{* * *}$ & 8.178 & -0.006 & -0.012 \\
\hline Guinea $(2005$ - 2012) & $0.642(0.005)$ & $0.614(0.007)$ & $-0.029^{* * *}$ & 3.211 & -0.004 & -0.007 \\
\hline Gambia $(2006$ - 2013) & $0.538(0.005)$ & $0.494(0.005)$ & $-0.043^{* * * *}$ & 5.705 & -0.006 & -0.012 \\
\hline Kenya $(2003$ - 2008/09) & $0.494(0.005)$ & $0.478(0.007)$ & $-0.016^{*}$ & 1.935 & -0.003 & -0.006 \\
\hline Kenya $(2008 / 9-2014)$ & $0.478(0.007)$ & $0.465(0.003)$ & $-0.012^{*}$ & 1.767 & -0.002 & -0.005 \\
\hline Kenya $(2003-2014)$ & $0.494(0.005)$ & $0.465(0.003)$ & $-0.029^{* * *}$ & 4.930 & -0.003 & -0.005 \\
\hline Liberia $(2007-2013)$ & $0.577(0.004)$ & $0.516(0.006)$ & $-0.062^{* * *}$ & 8.777 & -0.010 & -0.019 \\
\hline Lesotho $(2004-2009)$ & $0.468(0.003)$ & $0.450(0.004)$ & $-0.018^{* * *}$ & 3.231 & -0.004 & -0.008 \\
\hline Madagascar (2004 - 2008/9) & $0.558(0.006)$ & $0.565(0.004)$ & 0.007 & 0.940 & 0.002 & 0.003 \\
\hline Mali $(2006-2012 / 13)$ & $0.648(0.005)$ & $0.589(0.005)$ & $-0.059^{* * *}$ & 8.150 & -0.009 & -0.014 \\
\hline Mozambique (2003 - 2011) & $0.613(0.004)$ & $0.559(0.004)$ & $-0.054^{* * *}$ & 9.933 & -0.007 & -0.012 \\
\hline Mauritania $(2007-2011)$ & $0.572(0.004)$ & $0.546(0.004)$ & $-0.026^{* * * *}$ & 4.589 & -0.007 & -0.012 \\
\hline Malawi $(2004-2010)$ & $0.528(0.003)$ & $0.501(0.003)$ & $-0.027^{* * *}$ & 7.011 & -0.004 & -0.009 \\
\hline Namibia $(2000-2006 / 7)$ & $0.469(0.006)$ & $0.457(0.004)$ & $-0.012^{*}$ & 1.751 & -0.002 & -0.004 \\
\hline Namibia (2006/7 - 2013) & $0.457(0.004)$ & $0.443(0.006)$ & $-0.014^{* *}$ & 2.060 & -0.002 & -0.005 \\
\hline Namibia $(2000-2013)$ & $0.469(0.006)$ & $0.443(0.006)$ & $-0.026^{* * *}$ & 3.228 & -0.002 & -0.004 \\
\hline Niger (2006 - 2012) & $0.744(0.006)$ & $0.690(0.005)$ & $-0.054^{* * *}$ & 7.449 & -0.009 & -0.013 \\
\hline Nigeria $(2003-2008)$ & $0.579(0.007)$ & $0.573(0.004)$ & -0.006 & 0.696 & -0.001 & -0.002 \\
\hline Nigeria $(2003-2013)$ & $0.579(0.007)$ & $0.572(0.005)$ & -0.007 & 0.815 & -0.001 & -0.001 \\
\hline Nigeria $(2008-2013)$ & $0.573(0.004)$ & $0.572(0.005)$ & -0.001 & 0.224 & -0.000 & -0.000 \\
\hline Rwanda $(2010$ - 2014/15) & $0.499(0.003)$ & $0.481(0.003)$ & $-0.019^{* * *}$ & 4.500 & -0.004 & -0.008 \\
\hline Rwanda $(2005-2014 / 15)$ & $0.556(0.003)$ & $0.481(0.003)$ & $-0.075^{* * *}$ & 18.616 & -0.008 & -0.015 \\
\hline Rwanda (2005 - 2010) & $0.556(0.003)$ & $0.499(0.003)$ & $-0.056^{* * *}$ & 13.469 & -0.011 & -0.021 \\
\hline Senegal $(2010 / 11-2012 / 13)$ & $0.579(0.008)$ & $0.568(0.007)$ & -0.010 & 0.965 & -0.005 & -0.009 \\
\hline Senegal $(2005-2010 / 11)$ & $0.602(0.011)$ & $0.579(0.008)$ & $-0.024^{*}$ & 1.781 & -0.004 & -0.007 \\
\hline Senegal $(2005-2012 / 13)$ & $0.602(0.011)$ & $0.568(0.007)$ & $-0.034^{* *}$ & 2.583 & -0.005 & -0.008 \\
\hline Sierra Leone $(2008-2013)$ & $0.594(0.006)$ & $0.575(0.005)$ & $-0.019^{* * *}$ & 2.627 & -0.004 & -0.007 \\
\hline Sao Tome and Principe $(2000-2008 / 09)$ & $0.522(0.007)$ & $0.475(0.006)$ & $-0.048^{* * *}$ & 5.560 & -0.006 & -0.011 \\
\hline Togo $(2010$ - 2013/14) & $0.503(0.005)$ & $0.497(0.008)$ & -0.006 & 0.650 & -0.002 & -0.003 \\
\hline Tanzania (2008 - 2010) & $0.566(0.005)$ & $0.548(0.004)$ & $-0.018^{* * *}$ & 3.070 & -0.009 & -0.016 \\
\hline Uganda $(2006-2011)$ & $0.539(0.004)$ & $0.514(0.005)$ & $-0.025^{* * *}$ & 3.663 & -0.005 & -0.009 \\
\hline South Africa (2008 - 2012) & $0.424(0.004)$ & $0.408(0.004)$ & $-0.016^{* * *}$ & 2.749 & -0.004 & -0.009 \\
\hline Zambia $(2001 / 2$ - 2013/14) & $0.552(0.003)$ & $0.500(0.003)$ & $-0.052^{* * *}$ & 12.190 & -0.004 & -0.008 \\
\hline Zambia $(2007-2013 / 14)$ & $0.512(0.004)$ & $0.500(0.003)$ & $-0.012^{* * *}$ & 2.847 & -0.002 & -0.004 \\
\hline Zambia $(2001 / 2-2007)$ & $0.552(0.003)$ & $0.512(0.004)$ & $-0.040^{* * *}$ & 8.089 & -0.007 & -0.014 \\
\hline Zimbabwe (2010/11 - 2014) & $0.427(0.003)$ & $0.427(0.003)$ & 0.000 & 0.052 & 0.000 & 0.000 \\
\hline
\end{tabular}

Note: $* p<0.10 * * 0<0.05, * * * * 0.01$ (two-tailed tests); t-value for absolute change. 
Table 6: Highest performing regions

\begin{tabular}{|c|c|c|c|c|c|c|c|c|c|c|}
\hline Country & Region & $M P I$ in $t_{1}$ & $\triangle M P I$ & $\bar{\triangle} M P I$ & $H$ in $t_{1}$ & $\Delta H^{a}$ & $\bar{\Delta} H^{b}$ & $A$ in $t_{1}$ & $\Delta A^{a}$ & $\bar{\Delta} A^{b}$ \\
\hline Rep. of the Congo $(2009-2011 / 12)$ & Likouala & 0.389 & $-0.115 * * *$ & -0.046 & 0.739 & $-0.197 * * *$ & -0.079 & 0.526 & -0.021 & -0.008 \\
\hline Rep. of the Congo $(2009-2011 / 12)$ & Sangha & 400 & $-0.106 * \%$ & -0.042 & 662 & $-0.136 * \%$ & -0.054 & 0.604 & $-0.045 \%$ & -0.018 \\
\hline Rep. of the Congo $(2009-2011 / 12)$ & Cuvette-Ouest & 396 & $.096 \% * \%$ & -0.038 & 733 & $-0.132 \% * *$ & -0.053 & 0.541 & $-0.041^{* *}$ & -0.016 \\
\hline DR Congo $(2007$ - 2013/14) & Nord-Kivu & 0.588 & $-0.240 * * \%$ & -0.037 & .944 & $-0.274 * * *$ & -0.042 & 0.624 & $-0.103 * * \%$ & -0.016 \\
\hline Rep. of the Congo $(2009-2011 / 12)$ & Pool & 0.332 & $-0.092 * * *$ & -0.037 & 0.626 & $-0.135 \%$ & -0.054 & 0.530 & $-0.041 * * *$ & -0.017 \\
\hline Mauritania $(2007-2011)$ & Hodh Charghy & 0.552 & $-0.141 * * *$ & -0.035 & 0.918 & $-0.165 * * *$ & -0.041 & 0.602 & $-0.055 \% *$ & -0.014 \\
\hline DR Congo $(2007-2013 / 14)$ & Orientale & 0.606 & $-0.204 \% * *$ & -0.031 & 0.959 & $-0.184 * * *$ & -0.028 & 0.632 & $\because \%$ & -0.017 \\
\hline Mauritania $(2007-2011)$ & Gorgol & 0.576 & $-0.117 * * *$ & -0.029 & 0.886 & $-0.097 * * *$ & -0.024 & 0.650 & $-0.069 * * \%$ & -0.017 \\
\hline $\operatorname{Benin}(2006-2011 / 12)$ & Donga & 0.503 & $-0.159 \approx * \%$ & -0.029 & 0.868 & $-0.151 * * *$ & -0.027 & 0.579 & $-0.100 * \% *$ & -0.018 \\
\hline Ghana $(2003-2008)$ & Upper West & 0.518 & $-0.144 * \% *$ & -0.029 & 0.875 & $-0.154 * \% *$ & -0.031 & 0.593 & $-0.074 \% * \%$ & -0.015 \\
\hline Uganda $(2006-2011)$ & Western & 0.470 & $-0.143 * \% *$ & -0.029 & 0.869 & $-0.213 * * *$ & -0.043 & 0.540 & $-0.042 \% \%$ & -0.008 \\
\hline Mauritania (2007 - 2011) & Brakna & 0.420 & $-0.114 \% * \%$ & -0.028 & 0.767 & $-0.185 \% * \%$ & -0.046 & 0.548 & -0.021 & -0.005 \\
\hline DR Congo $(2007-2013 / 14)$ & Bandundu & 0.620 & $-0.184^{* * * * *}$ & -0.028 & 0.939 & $-0.102 \% * \%$ & -0.016 & 0.660 & $-0.140 * * *$ & -0.021 \\
\hline Mali $(2006-2012 / 13)$ & Koulikoro & 0.624 & $-0.184 * \% *$ & -0.028 & 0.927 & $-0.172 * * *$ & -0.026 & 0.673 & $-0.090 \% * \%$ & -0.014 \\
\hline Ghana $(2003-2008)$ & Eastern & 0.285 & $-0.141 * * * *$ & -0.028 & 0.567 & $-0.231 * * *$ & -0.046 & 0.502 & $-0.074 * * *$ & -0.015 \\
\hline Tanzania $(2008$ - 2010) & Zanzibar & 0.269 & $-0.056 \% * \%$ & -0.028 & 0.485 & $-0.071 * \%$ & -0.035 & 0.554 & $-0.040 \% * \%$ & -0.020 \\
\hline Rwanda (2005 - 2010) & North & 0.481 & $-0.139 * \cdots *$ & -0.028 & 0.866 & $-0.162 \% * \%$ & -0.032 & 0.556 & $-0.069 * * *$ & -0.014 \\
\hline Lesotho (2004 - 2009) & acha's-Nek & 0.354 & $-0.138 * \%$ & -0.028 & 0.704 & $-0.220 * * *$ & -0.044 & 0.502 & -0.056 & -0.011 \\
\hline Kenya $(2003-2008 / 09)$ & North Eastern & 0.681 & $-0.146 * \% *$ & -0.026 & 0.979 & $-0.096 \%$ & -0.017 & 0.695 & $-0.090 \% * \%$ & -0.016 \\
\hline Rwanda (2005 - 2010) & South & 0.469 & $-0.131 \% * \%$ & -0.026 & 0.838 & $-0.168 \% * *$ & -0.034 & 0.560 & $-0.056 \% * \%$ & -0.011 \\
\hline
\end{tabular}


Table 7: Ranking of absolute reductions in censored headcount ratios

\begin{tabular}{|c|c|c|c|}
\hline Country & Rank 1 & Rank 2 & Rank 3 \\
\hline Benin $(2001-2006)$ & attendance & mortality & toilet \\
\hline Benin $(2001-2011 / 12)$ & mortality & nutrition & attendance \\
\hline Benin $(2006-2011 / 12)$ & nutrition & mortality & electricity \\
\hline Burkina Faso (2003 - 2010) & attendance & water & nutrition \\
\hline Burundi (2005 - 2010) & assets & schooling & water \\
\hline C. African Republic (2000 - 2010) & attendance & schooling & mortality \\
\hline Cameroon $(2004-2011)$ & assets & toilet & electricity \\
\hline Comoros $(2000$ - 2012) & toilet & cooking & assets \\
\hline Cote d'Ivoire (2005 - 2011/12) & toilet & attendance & water \\
\hline DR Congo (2007 - 2013/14) & mortality & attendance & toilet \\
\hline Ethiopia $(2000-2005)$ & water & schooling & toilet \\
\hline Ethiopia $(2000-2011)$ & schooling & attendance & water \\
\hline Ethiopia $(2005$ - 2011) & attendance & schooling & electricity \\
\hline Gabon (2000 - 2012) & cooking & toilet & assets \\
\hline Gambia $(2006-2013)$ & electricity & nutrition & mortality \\
\hline Ghana $(2003-2008)$ & attendance & toilet & cooking \\
\hline Ghana $(2003-2014)$ & electricity & toilet & cooking \\
\hline Ghana (2008 - 2014) & electricity & floor & cooking \\
\hline Guinea $(2005$ - 2012) & schooling & assets & toilet \\
\hline Kenya $(2003-2008 / 09)$ & toilet & water & electricity \\
\hline Kenya $(2003-2014)$ & toilet & water & electricity \\
\hline Kenya $(2008 / 9-2014)$ & electricity & cooking & floor \\
\hline Lesotho $(2004-2009)$ & toilet & electricity & assets \\
\hline Liberia (2007 - 2013) & attendance & assets & electricity \\
\hline \multicolumn{4}{|l|}{ Madagascar (2004 - 2008/9) } \\
\hline Malawi (2004 - 2010) & water & assets & toilet \\
\hline Mali $(2006-2012 / 13)$ & mortality & assets & toilet \\
\hline Mauritania $(2007$ - 2011) & assets & water & toilet \\
\hline Mozambique (2003 - 2011) & toilet & schooling & electricity \\
\hline Namibia $(2000-2006 / 7)$ & assets & electricity & floor \\
\hline Namibia $(2000$ - 2013) & floor & electricity & toilet \\
\hline Namibia $(2006 / 7$ - 2013) & floor & electricity & toilet \\
\hline Niger $(2006-2012)$ & water & attendance & mortality \\
\hline Nigeria $(2003-2008)$ & toilet & water & mortality \\
\hline Nigeria $(2003-2013)$ & toilet & water & mortality \\
\hline Nigeria $(2008-2013)$ & mortality & & \\
\hline Rwanda (2005 - 2010) & toilet & water & assets \\
\hline Rwanda $(2005-2014 / 15)$ & toilet & water & electricity \\
\hline Rwanda (2010 - 2014/15) & mortality & electricity & cooking \\
\hline Sao Tome and Principe $(2000-2008 / 09)$ & toilet & assets & cooking \\
\hline Senegal $(2005-2010 / 11)$ & water & electricity & toilet \\
\hline Senegal $(2005-2012 / 13)$ & floor & schooling & mortality \\
\hline Senegal $(2010 / 11-2012 / 13)$ & floor & & \\
\hline Sierra Leone $(2008-2013)$ & schooling & attendance & water \\
\hline South Africa (2008 - 2012) & cooking & toilet & electricity \\
\hline Tanzania $(2008-2010)$ & toilet & assets & mortality \\
\hline The Republic of the Congo (2005 - 2009) & assets & cooking & water \\
\hline The Republic of the Congo $(2005-2011 / 12)$ & assets & cooking & toilet \\
\hline The Republic of the Congo $(2009-2011 / 12)$ & mortality & toilet & cooking \\
\hline Togo $(2010-2013 / 14)$ & assets & schooling & floor \\
\hline Uganda (2006 - 2011) & assets & water & toilet \\
\hline Zambia $(2001 / 2-2007)$ & attendance & assets & toilet \\
\hline Zambia $(2001 / 2$ - 2013/14) & assets & toilet & electricity \\
\hline Zambia $(2007-2013 / 14)$ & water & toilet & electricity \\
\hline Zimbabwe (2010/11 - 2014) & assets & mortality & \\
\hline
\end{tabular}

Note: If a specific entry is missing, the reduction was not significant. 
Table 8: Growth rate in GDP per capita

\begin{tabular}{|c|c|c|c|}
\hline \multirow{2}{*}{ Country } & \multicolumn{2}{|c|}{ GDP } & \multirow{2}{*}{$\begin{array}{c}\text { Annual growth rate } \\
t_{1}-t_{2}\end{array}$} \\
\hline & $t_{1}$ & $t_{2}$ & \\
\hline Benin $(2006-2011 / 12)$ & 591.4 & 610.7 & 0.6 \\
\hline Benin $(2001-2006)$ & 582.3 & 591.4 & 0.3 \\
\hline Benin $(2001-2011 / 12)$ & 582.3 & 610.7 & 0.5 \\
\hline Burkina Faso $(2003-2010)$ & 380.3 & 470.0 & 3.1 \\
\hline C. African Republic $(2000-2010)$ & 330.9 & 352.3 & 0.6 \\
\hline Cote d'Ivoire (2005 - 2011/12) & 942.2 & 884.7 & -1.0 \\
\hline DR Congo (2007 - 2013/14) & 223.8 & 268.3 & 2.8 \\
\hline The Republic of the Congo $(2009-2011 / 12)$ & 1827.7 & 1944.1 & 2.5 \\
\hline The Republic of the Congo $(2005-2009)$ & 1737.6 & 1827.7 & 1.3 \\
\hline The Republic of the Congo $(2005-2011 / 12)$ & 1737.6 & 1944.1 & 1.7 \\
\hline Ethiopia $(2005-2011)$ & 161.9 & 257.1 & 8.0 \\
\hline Ethiopia $(2000-2011)$ & 136.6 & 257.1 & 5.9 \\
\hline Ethiopia $(2000-2005)$ & 136.6 & 161.9 & 3.4 \\
\hline Ghana $(2003-2008)$ & 472.6 & 562.6 & 3.5 \\
\hline Guinea (2005 - 2012) & 303.8 & 303.5 & -0.0 \\
\hline Kenya $(2003-2008 / 09)$ & 501.7 & 558.7 & 2.0 \\
\hline Lesotho $(2004-2009)$ & 696.8 & 820.8 & 3.3 \\
\hline Madagascar (2004 - 2008/9) & 271.2 & 302.3 & 2.4 \\
\hline Mali $(2006-2012 / 13)$ & 433.8 & 445.7 & 0.4 \\
\hline Mozambique $(2003$ - 2011) & 330.7 & 473.3 & 4.6 \\
\hline Mauritania (2007 - 2011) & 802.2 & 793.0 & -0.3 \\
\hline Malawi (2004 - 2010) & 215.9 & 262.3 & 3.3 \\
\hline Namibia (2000 - 2006/7) & 3007.4 & 3785.4 & 3.6 \\
\hline Niger $(2006-2012)$ & 257.4 & 284.2 & 1.7 \\
\hline Nigeria $(2003-2008)$ & 612.0 & 912.5 & 8.3 \\
\hline Rwanda $(2005-2010)$ & 286.6 & 373.7 & 5.5 \\
\hline Senegal $(2010 / 11-2012 / 13)$ & 799.4 & 798.2 & -0.1 \\
\hline Senegal $(2005-2010 / 11)$ & 772.7 & 799.4 & 0.6 \\
\hline Senegal $(2005-2012 / 13)$ & 772.7 & 798.2 & 0.4 \\
\hline Sierra Leone $(2008-2013)$ & 354.3 & 501.7 & 7.2 \\
\hline Sao Tome and Principe $(2000-2008 / 09)$ & 734.9 & 940.2 & 2.9 \\
\hline Tanzania $(2008$ - 2010) & 487.6 & 513.0 & 2.6 \\
\hline Uganda (2006 - 2011) & 344.3 & 424.9 & 4.3 \\
\hline South Africa (2008 - 2012) & 5996.8 & 6051.3 & 0.2 \\
\hline Zambia $(2001 / 2-2013 / 14)$ & 598.0 & 1004.7 & 4.4 \\
\hline Zambia (2007 - 2013/14) & 764.7 & 1004.7 & 4.3 \\
\hline Zambia $(2001 / 2$ - 2007) & 598.0 & 764.7 & 4.6 \\
\hline
\end{tabular}

